\title{
APRS 70 anos: participe desta história
}

\author{
70 years of APRS: be a part of our history
}

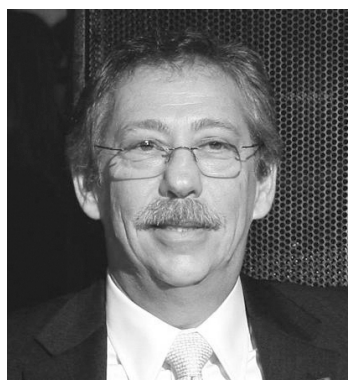

Colegas,

A Palavra do Presidente é uma tradição antiga na comunicação entre a diretoria da nossa Sociedade e os leitores da Revista de Psiquiatria do Rio Grande do Sul. É com muita satisfação que escrevo aos caros leitores ao se encerrar o primeiro ano da gestão 2008/ 2009 da Associação de Psiquiatria do Rio Grande do Sul. É verdade, estamos em pleno processo de elaboração dessa mudança de nome, que certamente ainda levará um bom tempo para que aconteça de fato - e então não mais mencionaremos "Sociedade" quando desejarmos nos referir a nossa instituição. $\mathrm{Na}$ realidade, essa modificação do nome foi em decorrência da necessidade de adequação às exigências legais do novo Código Civil, que está vigorando desde 2003. Então, a partir de setembro de 2008, após termos os novos estatutos oficialmente aprovados e registrados, passamos a ser Associação de Psiquiatria do Rio Grande do Sul (APRS).

A atual diretoria teve a felicidade de organizar a festa de comemoração dos 70 anos de existência da APRS, a qual ocorreu nas dependências da Associação Leopoldina Juvenil em 14 de novembro de 2008. Durante essa ocasião festiva, as funcionárias Silvia Regina Queiroz (20 anos de instituição) e Sandra Maria Schmaedecke (14 anos de instituição) foram homenageadas pelos relevantes serviços prestados à APRS. A psiquiatra Norma Utinguassu Escosteguy recebeu o prêmio Sócio Participação, justa homenagem por sua intensa e valiosa participação nas atividades científicas desenvolvidas pela nossa instituição. Também foi entregue o I Prêmio Cyro Martins de Incentivo à Pesquisa, aos psiquiatras Júlio Carlos Pezzi, Carolina Meira Moser e Ramiro Ronchetti. O prêmio, destinado aos melhores projetos de pesquisa desenvolvidos por psiquiatras em início de formação profissional, é uma homenagem ao centenário de nascimento do saudoso Dr. Cyro Martins, um dos fundadores da então denominada Sociedade de Neuro-Psiquiatria do Rio Grande do Sul, em novembro de 1938.

Ao longo desses 70 anos, a APRS passou por diversas e inevitáveis transformações. Graças ao trabalho contínuo, ao esforço de verdadeiros empreendedores e à dedicação de incontáveis colegas, foi possível a construção de uma associação capaz de desenvolver um conjunto de atividades científicas de alto nível. É possível afirmar com tranqüilidade que desenvolvemos uma identidade sólida como instituição representativa da psiquiatria do Rio Grande do Sul. Somos filiados à Associação Médica do Rio Grande do Sul (AMRIGS), à Associação Brasileira de Psiquiatria (ABP) e à World Psychiatric Association (WPA), e ainda é oportuno mencionar que apresentamos um crescimento notável, pois atualmente somos mais de 800 associados.

Ao iniciarmos um ano novo, é com muito prazer que anuncio mais uma comemoração: esta excelente Revista de Psiquiatria do Rio Grande do Sul, em 2009, completa 30 anos de existência e de publicação ininterrupta, uma conquista a mais da nossa APRS e que merece todos os elogios, uma vez que conhecemos de perto as enormes dificuldades relacionadas às publicações científicas em nosso país.

A organização da IX Jornada Gaúcha de Psiquiatria, cujo tema oficial é Sofrimento Psíquico: da Normalidade à Patologia, já está em andamento. Desde já, contamos com a mobilização e a participação dos associados para construirmos em conjunto este que será o grande evento científico da APRS em 2009. É com uma expectativa positiva em relação às nossas realizações que convido todos os colegas a participarem da nossa programação no próximo ano.

Afetuosamente,

Fernando Lejderman 